\title{
Dopamine-beta hydroxylase polymorphism and cocaine addiction
} Camila Guindalini $1,2,3,4$, Ronaldo Laranjeira ${ }^{5}$, David Collier 1,6 ,
Guilherme Messas ${ }^{4}$, Homero Vallada ${ }^{4,6}$ and Gerome Breen ${ }^{* 1,6}$

\begin{abstract}
Address: ${ }^{1}$ MRC Social Genetic and Developmental Psychiatry Research Centre, Institute of Psychiatry, King's College London, UK, ${ }^{2}$ Laboratório Integrado de Neurociências Clínicas, Department of Psychiatry, Federal University of São Paulo, Brazil, ${ }^{3}$ Department of Psychobiology, Federal University of São Paulo, Brazil, ${ }^{4}$ Department of Psychiatry, University of São Paulo, Medical School, Brazil, 5 UNIAD (Unit of Drug and Alcohol

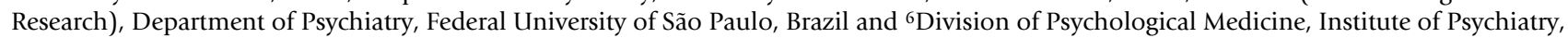
King's College London, UK

Email: Camila Guindalini - camilascg@gmail.com; Ronaldo Laranjeira - laranjeira@psiquiatria.epm.br; David Collier - d.collier@iop.kcl.ac.uk; Guilherme Messas - messas@netpoint.com.br; Homero Vallada - hvallada@usp.br; Gerome Breen* - g.breen@iop.kcl.ac.uk

* Corresponding author

Published: 3 January 2008

Behavioral and Brain Functions 2008, 4:I doi:10.1 186/1744-908I-4-I

Received: 25 September 2007

Accepted: 3 January 2008

This article is available from: http://www.behavioralandbrainfunctions.com/content/4/I/I

(C) 2008 Guindalini et al; licensee BioMed Central Ltd.

This is an Open Access article distributed under the terms of the Creative Commons Attribution License (http://creativecommons.org/licenses/by/2.0), which permits unrestricted use, distribution, and reproduction in any medium, provided the original work is properly cited.
\end{abstract}

\begin{abstract}
Cocaine addiction involves a number of medical, psychological and social problems. Understanding the genetic aetiology of this disorder will be essential for design of effective treatments. Dopaminebeta hydroxylase $(\mathrm{DbH})$ catalyzes the conversion of dopamine to norepinephrine and could, therefore, have an influence on both cocaine action and the basal sensitivity of neurotransmitter systems to cocaine. Recently, the - I02IC>T polymorphism have been found to strongly correlated with individual variation in plasma $\mathrm{DbH}$ activity. To test the influence of this polymorphism on the susceptibility of cocaine addiction, we decided to genotype it in a sample of 689 cocaine addicts and 832 healthy individuals. Genotypic and allelic analyses did not show any evidence of association with cocaine addiction, even after correcting for the effect of population stratification and other possible confounders. Our results do not support a major role of the - I02 IC>T polymorphism or the gene itself in the development of cocaine addiction but further examination of other variants within this gene will be necessary to completely rule out an effect.
\end{abstract}

\section{Findings}

Cocaine is one of the most powerfully addictive of the drugs of abuse. The number of cocaine users is estimated at some 13 million worldwide [1]. From those, 15-16\% will become addicted within 10 years of first cocaine use [2]. Twin and family studies have demonstrated that cocaine addiction has a strong genetic component but the exact basis of the heritable factors that have a significant contribution to this phenotype remain unclear [3].

Cocaine's potent actions in blocking the uptake by neuronal plasma membrane transporters for dopamine (DAT), serotonin (SERT), and norepinephrine (NET) are well known [4]. Studies in transgenic mice indicate that both DAT and SERT can mediate cocaine's rewarding effects, but the DAT may play the more important role [5]. On the other hand, mice lacking norepinephrine transporter demonstrated prolonged clearance of NE, elevated extracellular levels of this catecholamine and were behaviourally hypersensitive to cocaine and amphetamine, as measured by locomotor stimulation and conditioned place preference [6]. Similarly, double knockouts of both SERT and NET showed dramatically enhanced cocaine place preference [7]. 
Dopamine-beta hydroxylase ( $\mathrm{DbH}$ ) catalyzes the conversion of dopamine to norepinephrine (NE) and could, therefore, have an influence on both cocaine action and the basal sensitivity of neurotransmitter systems to cocaine [8]. It has been demonstrated that $\mathrm{DbH}$ knockout mice are hypersensitive to the psychomotor, rewarding, and aversive effects of cocaine, as measured by locomotor activity and conditioned place preference [9]. Pharmacological treatment studies with the $\mathrm{DbH}$ inhibitor disulfiram also indicate that this medication has efficacy as a treatment for cocaine dependence $[10,11]$.

DbH plasma activity levels are reported to vary widely among individuals [12]. Several studies have attempted to find genetic polymorphisms related to differences in enzyme levels. [13-15]. Cubells and colleagues found that a 19 base pair insertion/deletion polymorphism and the SNP 444A>G were associated with plasma DbH levels and that alleles of similar association to enzymatic levels were in significant positive disequilibrium. Additionally, the haplotype containing the two low DbH activity alleles was also associated with cocaine-induced paranoia [15].

More recently, using extreme phenotypes in samples from African and European American and Japanese populations, Zabetian and co-workers [16] reported that the $1021 \mathrm{C}>\mathrm{T}$ polymorphism ( $\mathrm{rs} 1611115$ ) located in the $5^{\prime}$ flanking region of the gene accounted for between 35$52 \%$ of the variation in plasma DbH activity in these populations. More strikingly, individuals with CC genotype had on average eleven times the enzyme activity of individuals carrying TT genotype [16]. Most recently, a study has shown that cocaine users homozygous for the T allele have an increased propensity to paranoia over time during cocaine self-administration [17].

However, no study has specifically tested the role of this variation in cocaine addiction aetiology, where it may be expected that individuals with the CC genotype might be more resistant to cocaine's effects. To verify the influence of this polymorphism on the susceptibility to cocaine addiction, we decided to conduct an association study in our previously described sample $[18,19]$ of 689 cocaine addicts and 832 healthy individuals, from Sao Paulo, Brazil.
The genotyping of the $-1021 \mathrm{C}>\mathrm{T}$ polymorphism was performed under contract by K-Biosciences (Cambridge, UK) blind to status using an amplifluor assay. Hardy-Weinberg equilibrium, genotype and allele frequencies were compared using a $\chi^{2}$ test and odds ratios and $95 \%$ confidence intervals were derived from logistic regression, using SPSS v12.0. We selected a total of 71 (64 SNPs and 7 microsatellites) ancestry-informative markers, e.g. markers that exhibit large allele frequency differences among the three main Brazilian ancestral populations (Europeans, Africans and Native American) to correct for potential population stratification in the sample, using the program ADMIXMAP [20]. The list of markers can be obtained upon request.

The genotype frequencies were in Hardy-Weinberg equilibrium in both, case and control groups for the -1021C>T polymorphism. The genotyping failure rate was around $3 \%$. Genotype counts and frequencies of the polymorphism in both groups, as well as allele wise odds ratios analyses, can be found in Table 1. Genotypic and allelic distribution did not provide any evidence for association between the marker and cocaine addiction $\left(\chi^{2}=1.01 ; \mathrm{df}=\right.$ $2 ; \mathrm{p}=0.59$ and $\chi^{2}=0.83 ; \mathrm{df}=1 ; \mathrm{p}=0.91 ; \mathrm{OR}=1.08$; $95 \% \mathrm{CI}=0.91-1.28)$. The correction for population stratification performed by ADMIXMAP did not affect the allelic association test $(\mathrm{z}=-0.626$; two-tailed $\mathrm{p}$ value $=$ $0.53)$. Further genotypic analyses, dividing the sample by sex, did not provide evidence of association for males $\left(\chi^{2}\right.$ $=0.83 ; \mathrm{df}=2 ; \mathrm{p}=0.66)$ and females $\left(\chi^{2}=0.19 ; \mathrm{df}=2 ; \mathrm{p}\right.$ $=0.91$ ).

Finally, evaluation of different models considering a dominant and a recessive effect for the low activity allele (T) also did not show difference between cases and controls, after correction for the potential confounding variables sex, age and education $(\mathrm{OR}=0.91 ; 95 \% \mathrm{CI}=0.72-1.15 ; \mathrm{p}$ $>0.05)$ and $(\mathrm{OR}=1.07 ; 95 \% \mathrm{CI}=0.66-1.74 ; \mathrm{p}>0.05)$.

The neurotransmitter norepinephrine and the norepinephrine transporter play an important role in the rewarding effects of cocaine [6,7], suggesting that genetic variation in the genes involved in the noradrenergic transmission could be responsible for differences in the individual response to cocaine. The $\mathrm{DbH}$ gene was an

Table I: Genotype and allele counts and frequencies (\%) of the - 102 IC>T polymorphism ( $r$ I I I I I I 5 ) in the DbH gene among healthy controls and cocaine addicts.

\begin{tabular}{|c|c|c|c|c|c|c|c|c|c|c|c|c|c|c|}
\hline \multirow[b]{3}{*}{ Controls } & \multicolumn{8}{|c|}{ Genotype-Wise } & \multicolumn{6}{|c|}{ Allele-Wise } \\
\hline & \multicolumn{2}{|c|}{ CC } & \multicolumn{2}{|c|}{ CT } & \multicolumn{2}{|c|}{ TT } & \multirow{2}{*}{$\begin{array}{c}\text { Total } \\
832\end{array}$} & \multirow{2}{*}{$\begin{array}{c}\text { pvalue } \\
0.59\end{array}$} & \multicolumn{2}{|c|}{ C } & \multicolumn{2}{|c|}{$\mathbf{T}$} & \multirow{2}{*}{$\begin{array}{c}\text { pvalue } \\
0.35\end{array}$} & \multirow{2}{*}{$\begin{array}{l}\text { OR (95\%IC) } \\
1.08(0.9-\mid .28)\end{array}$} \\
\hline & 487 & $59 \%$ & 294 & $35 \%$ & 51 & $6 \%$ & & & 1268 & $76 \%$ & 396 & $24 \%$ & & \\
\hline Cases & 421 & $61 \%$ & 228 & $33 \%$ & 40 & $6 \%$ & 689 & & 1070 & $78 \%$ & 308 & $22 \%$ & & \\
\hline
\end{tabular}


interesting candidate to test this hypothesis since it encodes for the enzyme responsible for the production of $\mathrm{NE}$ and consequently for the control of the NE/DA ratio in noradrenergic neurons. The strong association reported between $-1021 \mathrm{C}>\mathrm{T}$ genotypes and $\mathrm{DbH}$ levels, robustly indicated that this, or another polymorphism in very tight $\mathrm{LD}$, might be controlling the variation in enzymatic levels and NE synthesis observed across individuals [8] and could, therefore, account for increased susceptibility to abuse cocaine.

However, genotypic and allelic distribution, as well as the evaluation of recessive or dominant models for the low activity variant in a Brazilian sample of 689 cocaine addicts and 832 healthy controls did not provide evidence of association between this variant and the trait under study, even after correction for sex age, education and population stratification.

This is the first study examining the effect of polymorphisms in the DbH gene and the susceptibility to cocaine addiction utilizing a case-control approach. Cubells and co-workers (2000) [15] have studied cocaine dependent subjects and demonstrated an association with the low activity alleles of the insertion/deletion polymorphism and the SNP $444 \mathrm{~A}>\mathrm{G}$, but with the development of cocaine induced paranoia. The results of our study corroborate with the findings by Köhnke et al. (2002) [21] and Cubells (2002) [22]. Both groups demonstrated that plasma DbH activity was significantly lower in alcoholic subjects and in individuals with unipolar major depression with psychotic features, respectively. However, these positive associations were independent of genotype at $1021 \mathrm{C}>\mathrm{T}$, e.g. genotypic and allelic distribution for this polymorphism did not significantly differ between the groups under study. More recent studies also failed to find an association between this polymorphism and epilepsy [23], schizophrenia [24] and Tourette Syndrome [25].

In summary, our results do not support a specific role for the $-1021 \mathrm{C}>\mathrm{T}$ in cocaine addiction in the Brazilian population or a major role for variation in enzymatic activity of DbH. However, our study does not exclude a minor role for the $\mathrm{DbH}$ protein or its related pathway in the development of cocaine addiction and suggests that the examination of other variants within this gene not in close $\mathrm{LD}$ with the $-1021 \mathrm{C}>\mathrm{T}$ is necessary to completely rule out an effect.

\section{Competing interests}

The author(s) declare that they have no competing interests.

\section{Authors' contributions}

CG and GB analyzed the data, carried out statistical analysis and wrote the paper. RL was the psychiatrist coordina- tor of the sample collection. RL, DC and GM and HV participated in study design, and helped to revise drafts of the manuscript. All authors read and approved the final manuscript.

\section{Acknowledgements}

GB is support by a Wellcome Trust Value in People award. This work was in part supported by FAPESP (Fundação para o Amparo à Pesquisa do Estado de São Paulo) and CAPEs (Coordenação de Aperfeiçoamento de Pessoal de Nível Superior).

\section{References}

I. United Nations Office on Drugs and crimes [UNODC]: World Drug report. 2007.

2. Wagner FA, Anthony JC: From first drug use to drug dependence; developmental periods of risk for dependence upon marijuana, cocaine, and alcohol. Neuropsychopharmacology 2002, 26:479-488.

3. Kendler KS, Karkowski LM, Neale MC, Prescott CA: Illicit psychoactive substance use, heavy use, abuse, and dependence in a US population-based sample of male twins. Arch Gen Psychiatry 2000, 57:26I-269.

4. Kuhar MJ, Ritz MC, Boja JW: The dopamine hypothesis of the reinforcing properties of cocaine. Trends Neurosci 1991, | 4:299-302.

5. Sora I, Hall FS, Andrews AM, Itokawa M, Li XF, Wei HB, Wichems C, Lesch KP, Murphy DL, Uhl GR: Molecular mechanisms of cocaine reward: combined dopamine and serotonin transporter knockouts eliminate cocaine place preference. Proc Natl Acad Sci USA 2001, 98:5300-5305.

6. Xu F, Gainetdinov RR, Wetsel WC, Jones SR, Bohn LM, Miller GW Wang YM, Caron MG: Mice lacking the norepinephrine transporter are supersensitive to psychostimulants. Nat Neurosci 2000, 3:465-7I.

7. Hall FS, Li XF, Sora I, Xu F, Caron M, Lesch KP, Murphy DL, Uhl GR: Cocaine mechanisms: enhanced cocaine, fluoxetine and nisoxetine place preferences following monoamine transporter deletions. Neuroscience 2002, I I 5: I53-I6I.

8. Cubells JF, Zabetian CP: Human genetics of plasma dopamine beta-hydroxylase activity: applications to research in psychiatry and neurology. Psychopharmacology 2004, I 74:463-476.

9. Schank JR, Ventura R, Puglisi-Allegra S, Alcaro A, Cole CD, Liles LC, Seeman P, Weinshenker D: Dopamine beta-Hydroxylase knockout mice have alterations in dopamine signaling and are hypersensitive to cocaine. Neuropsychopharmacology 2006, 3 I:222 I -30.

10. Carroll KM, Nich C, Ball SA, McCance E, Rounsavile BJ: Treatment of cocaine and alcohol dependence with psychotherapy and disulfiram. Addiction 1998, 93:716-727.

II. George TP, Chawarski MC, Pakes J, Carroll KM, Kosten TR, Schottenfeld RS: Disulfiram versus placebo for cocaine dependence in buprenorphine-maintained subjects: a preliminary trial. Biol Psychiatry 2000, 47:1080-1086.

12. Weinshilboum RM, Raymond FA, Elveback LR, Weidman WH: Serum dopamine-beta-hydroxylase activity: sibling-sibling correlation. Science 1973, I 81:943-945.

13. Wei J, Ramchand CN, Hemmings GP: Possible control of dopamine beta-hydroxylase via a codominant mechanism associated with the polymorphic (GT)n repeat at its gene locus in healthy individuals. Genet 1997, 99:52-55.

14. Cubells JF, van Kammen DP, Kelley ME, Anderson GM, O'Connor DT, Price LH, Malison R, Rao PA, Kobayashi K, Nagatsu T, Gelernter J: Dopamine beta-hydroxylase: two polymorphisms in linkage disequilibrium at the structural gene DBH associate with biochemical phenotypic variation. Hum Genet 1998, 1 02:533-540.

15. Cubells JF, Kranzler HR, McCance-Katz E, Anderson GM, Malison RT, Price LH, Gelernter ]: A haplotype at the DBH locus, associated with low plasma dopamine beta-hydroxylase activity, also associates with cocaine-induced paranoia. Mol Psychiatry 2000 , 5:56-63.

16. Zabetian CP, Anderson GM, Buxbaum SG, Elston RC, Ichinose H, Nagatsu T, Kim KS, Kim CH, Malison RT, Gelernter J, Cubells JF: A 
quantitative-trait analysis of human plasma-dopamine betahydroxylase activity: evidence for a major functional polymorphism at the DBH locus. Am J Hum Genet 200I, 68:5 I 5-522

17. Kalayasiri R, Sughondhabirom A, Gueorguieva R, Coric V, Lynch WJ, Lappalainen J, Gelernter J, Cubells JF, Malison RT: Dopamine betaHydroxylase Gene [DbetaH] - I02IC-->T Influences SelfReported Paranoia during Cocaine Self-Administration. Biol Psychiatry 2007, 61:1310-3.

18. Guindalini C, Howard M, Haddley K, Laranjeira R, Collier D, Ammar N, Craig I, O'Gara C, Bubb VJ, Greenwood T, Kelsoe J, Asherson P, Murray RM, Castelo A, Quinn JP, Vallada H, Breen G: A dopamine transporter gene functional variant associated with cocaine abuse in a Brazilian sample. Proc Natl Acad Sci USA 2006, 103:4552-7.

19. Guindalini C, Vallada H, Breen G, Laranjeira R: Concurrent crack and powder cocaine users from Sao Paulo: do they represent a different group? BMC Public Health 2006, 6(I 0):-.

20. McKeigue PM, Carpenter JR, Parra EJ, Shriver MD: Estimation of admixture and detection of linkage in admixed populations by a Bayesian approach: application to African-American populations. Ann Hum Genet 2002, 64:17I-186.

21. Kohnke MD, Zabetian CP, Anderson GM, Kolb W, Gaertner I, Buchkremer G, Vonthein R, Schick S, Lutz U, Kohnke AM, Cubells JF: A genotype-controlled analysis of plasma dopamine betahydroxylase in healthy and alcoholic subjects: evidence for alcohol-related differences in noradrenergic function. Biol Psychiatry 2002, 52:1 I II-1158.

22. Cubells JF, Price LH, Meyers BS, Anderson GM, Zabetian CP, Alexopoulos GS, Nelson JC, Sanacora G, Kirwin P, Carpenter L, Malison RT, Gelernter J: Genotype-controlled analysis of plasma dopamine beta-hydroxylase activity in psychotic unipolar major depression. Biol Psychiatry 2002, 5 I :358-364.

23. Depondt C, Cock HR, Healy DG, Burley MW, Weinshenker D, Wood NW, Goldstein DB, Sisodiya SM: The - 102 I C >T DBH gene variant is not associated with epilepsy or antiepileptic drug response. Neurology 2004, 63:1497-1499.

24. Jonsson EG, Abou Jamra R, Schumacher J, Flyckt L, Edman G, Forslund K, Mattila-Evenden M, Rylander G, Asberg M, Bjerkenstedt L, Wiesel FA, Propping P, Cichon S, Nothen MM, Sedvall GC: No association between a putative functional promoter variant in the dopamine beta-hydroxylase gene and schizophrenia. Psychiatr Genet 2003, 13:175-178.

25. Ozbay F, Wigg KG, Turanli ET, Asherson P, Yazgan Y, Sandor P, Barr $C L$ : Analysis of the dopamine beta hydroxylase gene in Gilles de la Tourette syndrome. Am J Med Genet B Neuropsychiatr Genet 2006, I 1 I:673-7.
http.//Www.behavioralandbrainfunctions.com/content/4/1/1 